\title{
THE ACTIVITIES OF A LOCAL GOVERNMENT ENTITY DURING PANDEMIC CONDITIONS USING ZABRZE AS AN EXAMPLE
}

\author{
Małgorzata MAŃKA-SZULIK ${ }^{1}$, Dariusz KRAWCZYK ${ }^{2 *}$ \\ ${ }^{1}$ Prezydent miasta Zabrze; prezydent@um.zabrze.pl; ORCID: 000-0002-5328-8736 \\ ${ }^{2}$ Naczelnik Wydziału Kontaktów Społecznych Urzędu Miejskiego w Zabrzu; d.krawczyk@olpress.pl; \\ ORCID: 0000-0003-1823-0309 \\ * Correspondence author
}

Purpose: The presentation of measures taken within the Polish city with poviat rights, which is Zabrze, to mitigate the spread of SARS-CoV-2 coronavirus, secure the functioning of local administration structures and ensure the work of institutions and companies subordinate to local government in the light of the pandemic in 2020.

Methodology: The process of involvement of municipal entities in the activities of government anti-crisis services, the specificity of performing tasks for the benefit of the local community and taking initiatives to mitigate the effects of the pandemic in particular segments of the inhabitants' life activity was shown.

Findings: The implemented management procedures for the planning and coordination of measures to reduce the negative social and economic effects caused by coronavirus were presented.

Practical implications: The record and analysis of the measures taken by the local government administration together with its subordinate entities in the event of a crisis may serve to optimise planning activities in case of a similar threat.

Exceptionality: The activity of individual entities, institutions and services was a reaction to an exceptional epidemic situation, which affected all spheres of social and economic life, and therefore required a conscious crisis management.

Keywords: coronavirus, municipal government, crisis management, information policy.

\section{Introduction}

The first case of SARS-CoV-2 infection in Poland was reported on 4 March 2020, which was confirmed by Łukasz Szumowski, Minister of Health ${ }^{1}$. The activity of municipal government entities during that period had to be oriented towards protecting the inhabitants

\footnotetext{
${ }^{1}$ The first case of coronavirus in Poland, announcement in the Internet Service of the Republic of Poland at https://www.gov.pl [accessed 28 May 2020].
} 
from the epidemic threat and engaging in the governmental system of limiting the effects of the pandemic. The municipal government implemented and supervised subsequent social isolation procedures, and at the same time carried out activities in the field of crisis management (e.g. creating isolatories, disinfecting public space, distributing protective measures, etc.) and broadly understood social assistance and medical care (e.g. providing food and medicine to people in quarantine, organising campaigns to collect swabs for coronavirus tests, etc.). These types of activities were also accompanied by a public communication campaign aimed at providing the inhabitants with information about safety rules during a pandemic, as well as updating them on current events, actions and initiatives relevant to the local community. Some of the local administration resources were also directly transferred to the state structures like the city guard. Additionally, activities related to ensuring the functioning of the local government community in epidemic conditions were conducted. These included providing medical care, education, transport, municipal management, environmental protection, etc. Another form of engagement of local government entities was the creation of legal solutions allowing to provide support to local entrepreneurs and residents who use municipal premises or services of municipal companies. The final phase included activities associated with the reduction of epidemiological restrictions and restoring normal functioning of local government administration, entities, institutions and companies and all other entities in the city.

\section{Municipal government with regard to pandemic restrictions}

After 4 March 2020, mass events and meetings with residents were gradually called off in Zabrze. Also, higher standards of sanitary safety were introduced, and in the structures of the municipal office and subordinate entities remote working systems were implemented and adjusted to the recommendations of the government administration. During meetings held on 12 March with presidents of municipal companies, directors of organisational entities and directors of kindergartens, schools and educational institutions, the subject of epidemic risk was raised, whereas in the case of educational institutions, up-to-date information was provided by the Ministry of National Education.

It was stated that all activities should be conducted on the basis of the provisions of the Act on special solutions related to the prevention, counteraction and combating of COVID-19, other infectious diseases and crisis situations caused by them (Journal of Laws of 7.03.2020, item 374) and communications published by the Chief Sanitary Inspectorate and State Crisis Management Services.

Quarantine facilities for one hundred sixty people have been provided in the building of the Municipal School Dormitory located at 13 Franciszkańska Street. As part of this task, lighting and heating of the rooms, beds with bedding, food for those directed to the facility and cleaning, 
disinfection, waste disposal and other services essential for the operation of the facility were provided.

The municipal services constantly monitored the situation while keeping in contact with voivodeship and national anti-crisis management structures.

\subsection{Appointment of the task force}

One of the first reactions to the threat situation caused by the pandemic was to appoint a task force at the Zabrze City Hall. The task of an interdisciplinary and interdepartmental group of officials, having expertise in various fields, was to provide quick and efficient crisis management support. The team dealt with the problems resulting from the epidemic situation. For instance, a group of twenty-two students from educational institutions in Zabrze, who stayed in Spain, was brought back to Poland. The students participated in the internship in Córdoba. They left there on 29 February. The internship was organised within the framework of the 'POWER - Work reality in Spain' programme. In the light of the rapidly developing situation related to the SARS-CoV-2 pandemic, project coordinators from the Department of Education of the Zabrze City Hall decided to shorten the stay of students. On 11 March, they made several attempts to purchase airline tickets, which were unsuccessful due to the lack of seats on the planes. As the epidemic situation worsened, it was decided to bring in students immediately. On 12 March it was decided that the students should return to Poland by coach. Within the framework of cooperation with the Ministry of Foreign Affairs and a group of Border Guard officers, the route and details of the coach were given to all services of transit countries. Also, the information about plans to introduce a state of emergency in Spain was obtained. As a result, students were transported over a distance of 1,000 km by coach of the Spanish partner of the project to the Spanish-French border. There, the students stayed in a hotel, waiting for the bus to arrive from Poland. On 15 March, at 2.50 a.m., the group crossed the Spanish-French border and then moved towards the border with Germany. The Ministry of Foreign Affairs services informed about the planned closure of the French-German border, which was to take place on $16 \mathrm{March}$, at $8.00 \mathrm{a} . \mathrm{m}$. The coach with students was then located near Lyon. Due to the heavy traffic, it was not possible to reach the border before it was closed. The task force then contacted the Ministry of Foreign Affairs to allow students to cross the French-German border. A border crossing point was designated, which the coach could use to cross without any problems. The transit through Germany went without any disruptions. Around 3.00 a.m. a group of students arrived at the Polish border, where they had to wait many hours to enter the country. There was a way to shorten the time of the journey, which involved sending another coach from Zabrze. The students crossed the border in Zgorzelec on foot, and then they went to Zabrze by the second coach. This action shortened the journey by about fifteen hours. On 17 March, the group reached Zabrze and was sent to a quarantine point organised by the city, where they spent another two weeks. 


\subsection{The changes in the functioning of local administration}

On 16 March 2020, changes were introduced (announced on 13 March) in the functioning of the Zabrze City Hall, resulting in the fact that it did not fully provide direct, publicly available customer service (related to the personal visit of customers). The Customer Service Point operating at the M1 Shopping Centre in Zabrze was also closed from 13 March. Since 12 March, all meetings of non-governmental organisations and informal groups at the NGO Centre have been cancelled. All meetings with residents have been cancelled as well.

Primarily, all matters were dealt with by phone, e-mail or traditional mail. At the entrance to the Zabrze City Hall building, a temporary letterbox was installed where residents could submit documents.

In the assigned catalogue of cases in which a personal visit to the City Hall was necessary, it was obligatory to make an appointment by phone for a specific time and date. This concerned: registration of marital status, population register and ID cards, issuing driving licenses, registration cards and other transportation documents, architectural and construction administration, environmental protection, use of water within the scope of water law consent, provision of municipal services and handling entries in the Central Register and Information on Economic Activity. A special helpline with three telephone numbers was also launched, where officials provided information on the form of handling individual issues.

The address of the Bulletin of Public Information (www.bip.um.zabrze.pl) was also published, with a bookmark that allows the use of the electronic mailbox [ESP].

For security reasons, the session of the Zabrze City Hall took place on 16 March without the participation of guests and the public. The councillors' duty was also cancelled. On 17 March, due to the epidemiological threat and the recommendations of the Chief Sanitary Inspector to prevent the spread of Coronavirus (SARS-COV-2), the Zabrze City Hall suspended all its standing committees. In April and May, the City Hall sessions were held remotely.

\subsection{The changes in the activity of selected municipal entities}

The restrictions were also introduced in municipalities within the city. These were mainly based on the avoidance of direct contacts with customers in favour of remote communication tools. For example, on 13 March, the Municipal Road and IT Infrastructure Management Board in Zabrze introduced limited access to the premises and personnel of the entity by designating an entry window and closing the main entrance.

The Family Benefits Centre in Zabrze has introduced a restrictions on visits. Since 16 March, the building of the District Labour Office was closed, and for the purpose of dealing with necessary matters, the clients were consulted by phone or e-mail.

The Zabrze Centre for Supporting Entrepreneurship provided telephone contact with advisors for entrepreneurs. 
Since 13 March, Zabrze Water Supply and Sewerage Company has limited direct contacts with customers. All matters were dealt with by phone or e-mail. The commissioning and additional services were also suspended.

Pursuant to the decision of the Chairperson of the Poviat Disability Evaluation Board of 16 March, the tasks were performed with the exclusion of direct service of clients who could contact them by mail, through the electronic mailbox [ESP] on the website, by e-mail or by phone.

The Municipal Family Assistance Centre provided psychological support remotely in the Crisis Intervention Team through the WhatsApp application (this way it was also possible to make video calls) and by phone and e-mail.

As of 11 March, the nursing homes introduced a total ban on the visits of the patients there.

The Psychological and Pedagogical Counselling Centre limited its work to telephone and e-mail contact. Personal legal advice and mediation have also been suspended. Legal and civic advice was offered over the phone or by e-mail at fixed hours after the contact was previously arranged by phone.

The Centre for the Addiction Prevention and Treatment introduced tele-advice possibilities. People in a state of mental crisis could take advantage of the tele-advice provided by specialists in addiction psychotherapy, psychotherapists, psychiatrists and psychologists.

Patients of the so called 'night and holiday medical care' were obliged to use tele-advice service, during which the doctor determined whether a personal visit of the patient to the clinic was necessary.

In municipal public transport in Zabrze, timetables valid for 'non-school working days' are in effect. Due to the cooperation with the Silesian Voivodeship Branch of the National Health Fund, posters were put up in the vehicles informing passengers about how to prevent the infection. Moreover, the Metropolitan Transport Authority conducted increased vehicle cleanliness inspections of all its carriers.

From 16 March, the activity of the Non-Public Healthcare Centre Caritas of Gliwice Diocese and subordinate organisational entities was limited. Nursing, care and nursing services were provided only in emergency situations, after prior telephone contact with the representative of the care centre.

As a consequence of the amendments made by the government to the regulation on the carrying out of the military qualification in 2020, this qualification was completed on 13 March. All calls for conscripts to appear between 16 March and 30 April are no longer valid.

The restrictions did not omit the sphere of spiritual life of the inhabitants. By decree of Jan Kopiec, Bishop of Gliwice Diocese, in relation to the introduction of a state of epidemic danger in Poland, scheduled services in all churches and chapels of Gliwice Diocese were cancelled by 13 March. The priests celebrated the scheduled masses in the parish churches or chapels, according to the intentions set for those days, but without the participation of the congregation. 


\section{Local government planning, organising and coordinating support for residents}

Together with the introduction of necessary restrictions resulting from the need to maintain social isolation, measures were implemented to help the local community of Zabrze. In the Municipal Family Assistance Centre a Team for Coordination of Support for Quarantined People was established. It operated from 7.30 a.m. to 7 p.m. seven days a week. The team was in charge of informing and coordinating assistance activities for the benefit of residents both in and outside the compulsory quarantine, and who are at risk (e.g. seniors, ill and disabled people).

In order to streamline work and minimise the risk of virus infection among residents and employees, the centre created a deposit account to which funds were transferred from those wishing to benefit from the purchases of food and medicine made by employees. The team received about a few dozen applications a day.

The cooperation was established with shops, pharmacies and gastronomic businesses, which offered services as well as delivery to the place of residence. As part of social work, employees provided advice on contact with institutions and assistance in setting up bank accounts, organising prescriptions at health clinics (e-prescriptions) or initiating neighbourly as well as family support. Moreover, deaf and hearing-impaired people were able to use the video helpline. The tool worked on a 24-hour basis. They could also communicate with a sign language interpreter via instant messaging services (e.g. WhatsApp) in the form of a video call every Tuesday.

\subsection{The virtual activity of cultural institutions}

Zabrze is a regional centre of the industrial heritage tourism. On 10 March, following the decision of the Prime Minister to discontinue mass events and the recommendations of the Chief Sanitary Inspector to counteract the spread of coronavirus (SARS-Cov-2), the tourist traffic was stopped at the historic Guido Coal Mine and the Queen Luisa Adit. It was decided that in 2020 there will be no regular International Conference and International Tourism Fair of Industrial Heritage. Consequently, all events in all the city's cultural, artistic and recreational facilities were cancelled.

Due to the pandemic, the cultural activity of Zabrze's institutions and entities moved to the Internet. It is worth mentioning examples of proposals of cultural institutions operating in Zabrze: (1) Teatr Nowy in Zabrze: Actors read 'Wiersze na dobranoc' (Good night poems) daily at 6.30 p.m. on the Facebook fanpage of the theatre. Teatr Nowy also prepared 'Lekcje o teatrze, nie tylko Nowym' (Lessons about theatre, not only the New), in which you can take part on the Facebook profile. On 25 March, the theatre made available to the older audience a performance entitled 'Pokój zwierzeń' (The Confession Room) in an on-line version. On 3 April, another 
series on Facebook profile started — 'Muzyczne Piątki' (Music Fridays). (2) The Zabrze Philharmonic: music publications were made available on Facebook - fragments of the concert which took place on 6 March were presented. The headliner for the evening was Maciej Zakościelny, a well-known Polish film actor; or Bartosz Chajdecki's composition, who is the author of the music for the series 'Czas honoru' (Days of Honour). On 1 April, a unique project was presented to music lovers. Sixteen musicians recorded remotely composed the song 'To My' (That is us) by the late Wiesław Świderski. This project was an expression of gratitude and solidarity with all those who have fought against the epidemic. (3) Municipal Cultural Centre: a performance inspired by the 'Księga Dżungli' (The Jungle Book) was made available on Facebook, the viewers were encouraged to browse through photographic archives and send their works to the 'Kreatywne Zabrze' (Creative Zabrze) contest, guests were invited to the online exhibition 'Kobieca nostalgia' (Woman's Nostalgia) by Halina Matłosz or the Gala Concert of the VIII National Festival Igraszki 2019. (4) The Coal Mining Museum: on 25 March, the 'Podziemna Szkoła' (Underground School) project presenting mining culture was created on a Facebook profile. An interesting proposal was also a series of films, which allowed to visit post-industrial tourism facilities without leaving home. (5) Municipal Public Library: in cyberspace, readers were encouraged to take part in many projects, including: online meetings with authors (e.g. Wojciech Chmielarz, Grzegorz Piątek or Marcin Dudziński). The library also prepared a list of places to download free e-books.

Moreover, the XIII edition of the Metropolitan Family Day took place in cyberspace, where also the First Metropolitan Literary Contest was organised. Similarly to the XXIII International Drawing Festival, which was exceptionally not a competition, but a promotion of art and works of the participants.

\subsection{The functioning of the education system}

On 16 March pursuant to the Regulation of the Minister of National Education of 11 March 2020. (Journal of Laws of 11.03.2020, item 410), all classes in educational institutions were suspended (on 12 and 13 March there was only student-supervision organised). The Ministry of National Education has stated that it is the decisions of the directors of educational institutions that determine how the work of the employees of these institutions is organised. The Ministry also encouraged teachers to support students in learning and to provide materials for independent work at home.

Parents have been asked, via the City Hall's website (www.um.zabrze.pl) and the city's Facebook profile, to familiarise themselves with and comply with the prevention policies provided by crisis management centres and sanitation services.

Since 25 March there has been an obligation to implement the core curriculum using distance learning methods and techniques. Thus, in Zabrze, discussions were held, among others, with school and kindergarten headmasters and the Polish Teachers' Union 
representatives [ZNP] as well as the Solidarity Trade Union [NSZZ 'Solidarność'] on how to implement the tasks of educational institutions with the use of distance learning.

The primary schools in Zabrze were equipped with three hundred fifty tablets, purchased from the city's budget (the cost of purchase of one hundred seventy-five of them for forty-one schools, in the amount of PLN 100,000 was reimbursed under the Operational Programme Digital Poland for 2014-2020). Another application for the purchase of tablets and laptops was also submitted.

The Zabrze City Hall, the Centre for Practical and Continuing Education and the local governmental TV Zabrze - Cultural Information Centre have made an attempt to present the offer of secondary schools in Zabrze to students finishing their education in the eighth grade of primary schools. The editors placed in their program information videos sent by secondary schools in Zabrze. (Internet broadcasts and digital platform - TV channel 140 of Vectra TV) and in virtual space (YouTube and Facebook profile).

\subsection{The activities of the City Guard}

In compliance with the government decisions, all forces and resources of the City Guard were made at the disposal of the police force. As part of the preventive measures, the city guards patrolled the places where children and young people gathered. They informed about the need to stay in the flats. They provided information about health threats resulting from the presence of a larger number of people in a small space. These activities were paralleled with similar activities of the police and performed alternately during the day. Every day, a dozen or so city guards, together with police officers from particular police stations (in mixed patrols), carried out tasks related to verification of execution of orders, prohibitions and obligations resulting from the prevention of the spread of SARS-CoV-2. The areas around the residential housing developments and (then closed) shopping and entertainment centres were particularly controlled.

The officers sent on patrols were equipped with masks to protect their upper respiratory tract and thermometers. Together with the Municipal Family Assistance Centre, a procedure was established for responding to residents' requests for assistance to the elderly and ill, who were in the group of higher risk of infection. Support was also provided to people in quarantine. The assistance primarily consisted in the delivery of food parcels, but also e.g. collecting rubbish from quarantined people in the place of residence, and coordinating the flow of information concerning people in need of help in this regard.

In cases of extreme irresponsibility, fines were imposed on the violators during proceedings by penal orders, and in situations of extreme disregard for the rules, official notes were made. These were then forwarded to the relevant Sanitary and Epidemiological Station, which could impose an administrative penalty of a maximum of PLN 30,000. 
In the first half of May 2020, the city guards delivered disinfectants to care and educational institutions, kindergartens and nurseries. These activities are the result of cooperation between the Department of Crisis Management and Civil Protection, the Department of Health and Social Care and the Department of Education of the Zabrze City Hall. In total, forty-one kindergartens and seventeen kindergartens received support.

\subsection{Direct support to the Polish government measures}

Although the Polish government was responsible for the implementation of the measures to directly combat the pandemic, the local government launched the so-called 'Swab-Bus', a mobile swab collection point for coronavirus tests. This allowed to test about twenty-five residents of Zabrze more every day. As part of the service commissioned by the city, a specialised company collected the necessary reagents from the Silesian Voivodeship Office in Katowice as well as lists of people who, according to the decision made by the Sanitary and Epidemiological Station, were to be tested. Then, the employees visited the people in quarantine indicated by the Sanitary and Epidemiological Station and took samples from them.

Together with the city of Zabrze - Kardio-Med Silesia Medical Technology Park started tests for SARS-CoV-2 virus on 27 March. The Silesian Voivode decided to equip Kardio-Med Silesia with additional analytical apparatus so that the tests could be conducted even more efficiently. The measures taken allow to increase the number of tests carried out in the Silesian Voivodeship. The tests were carried out only on behalf of designated hospitals, from where the previously collected swabs were delivered to Kardio-Med Silesia. Since 6 April, after obtaining certificates and approvals from the Voivodeship Sanitary and Epidemiological Station in Katowice and the National Institute of Hygiene in Warsaw, a new genetic laboratory Covid-19 was operating in Kardio-Med Silesia, in which samples from the whole Silesian Voivodeship were examined.

Additionally, The Department of Crisis Management and Civil Protection has been carrying out disinfection of public transport stops once a week since 1 April. Bus shelters, benches and showcases as well as the area around the stops were disinfected. The disinfection of over two hundred locations was commissioned to the Zabrze-based company WC Serwis, which provides services for mass events on a daily basis. In this way, the city was also supporting the local company.

The Zabrze City Hall also purchased, among others, two innovative 'VENTIL' devices, i.e. devices enabling breathing two patients with one respirator. The equipment was handed over to the Municipal Hospital in Zabrze. 


\subsection{Integration and activation initiatives}

The local government also supported social initiatives which, apart from providing respiratory protection, were aimed at activating and integrating residents. Employees of institutions and companies got involved in the activity. For instance, employees of the Coal Mining Museum donated hand-made face masks for residents of nursing homes. However, for the Municipal Hospital in Zabrze the face masks were hand-sewn by the senior citizens of Zabrze. Non-governmental organisations and associations have also gathered around themselves many people who sewed face masks. Hundreds of them were given, among others, to the Municipal Hospital in Zabrze, the Silesian Centre for Heart Diseases, the Nursing Home in Tarnowskie Góry, MOPR Zabrze - District Nursing Points and the Nursing Home run by the Camillian Order in Zabrze.

On 30 April, the campaign 'Maseczka w miasto' [Face mask in the city], which was carried out by cultural institutions in Zabrze, began. The aim of the campaign was to increase the safety of residents by providing them with protective masks. The so-called 'Face Mask Bus' regularly came to new districts of Zabrze, where cotton reusable face masks were given to those willing to receive them.

\section{Information and communication initiatives addressed to residents}

All decisions taken and activities resulting from them had to be properly communicated. In order to do this, crisis communication procedures were launched, which were created beforehand to ensure not only that the message reached the right target groups, but also to prevent manipulation, rumours and panic spread. Nowadays, even in the case of institutionalised media, but especially Internet broadcasters, inaccurate, unverified or even untrue information is a real threat. In the social media world, however, the issue of publishing lies or defamation has become widespread. To ensure the safety of the audience of these media, an attempt had to be made to counteract the spread of the so-called 'fake news' or to limit the social effects of Internet 'haters activity', because "it is difficult to assume that the strengthening of legal regulations or educational actions and social campaigns will allow for the complete elimination of this form of electronic aggression. Therefore, it is worth taking management actions from the perspective of the entity consisting, on the one hand, in preventive actions and, on the other, in the development and implementation of procedures for the time of real proceedings in the face of a crisis situation" (Kaczmarek-Śliwińska, 2020, p. 86). The goal of a conscious information policy during the pandemic was to present local events on a daily basis, in a regional and national context, allowing to rationalise the perception of the situation in the city. 
The perception of danger was influenced by various factors. The level of education, state of prosperity, place of residence and, above all, belonging to a specific age category were significant. This is demonstrated, among others, by analyses conducted among students of the Pedagogical University named after the Commission of National Education in Kraków, where "almost three-quarters of the respondents believe that the coronavirus poses a serious threat to the health and life of our country's inhabitants. However, to a lesser extent, the students believe that the virus may pose a threat to themselves. Only one-third stated that the coronavirus is dangerous for them. The level of fear of infection is also low" (Długosz, 2020, p. 25). It was therefore necessary to develop and distribute messages to specific target groups. The segmentation of the media auditorium allowed for the publication of content addressed both to people who were actually most at risk from the effects of the epidemic and to people who, while considering the risk of infection relatively low, had to comply with oppressive rules of social isolation.

In the first phase, the priority was to act specifically to introduce restrictions. They were accompanied by a comprehensive information campaign. In Zabrze, as in other cities, decisions were also taken to facilitate functioning in a state of epidemic danger. Since the beginning of the pandemic, the information addressed to the inhabitants was published on the distribution media under the responsibility of the local government, from the beginning of the pandemic, by the Ministry of Health, the National Health Fund, the Chief Sanitary Inspector, as well as the Department of Crisis Management and Civil Protection of the Zabrze City Hall. The basic channels of information distribution were communication tools using the potential of cyberspace: the city's website, social media profiles, broadcasts of the local government's TV Zabrze, newsletters, e-mails, etc. Further areas were media relations activities conducted in cooperation with commercial media (mainly radio and television stations and Internet broadcasters). Obviously, the importance of announcements made public by means of traditional paper press (both regional and local commercial as well as the local government periodicals) has dramatically decreased, but not their Internet portals and editorial profiles in social media.

The media provided information about the coronavirus, the symptoms of the disease it causes, safety rules, risk groups and guidelines on how to deal with suspicion of infection, including the data of isolation hospitals and those that had infectious diseases wards in the region. The communication was constructed taking into account the visual attractiveness, which improved its social coverage. The information was constantly updated. It is important to emphasise the factual nature of the messages, which were to indicate the actual state of affairs and not generate fear, because "the fear is an extremely destructive emotion. Not only does it make thinking more difficult, it often makes it impossible, making people act not to improve their situation, but to reduce the fear that takes away the desire to live, withdrawing from any social activity" (Szpunar, 2020, p. 28). 


\section{Measures to stimulate the economic and social situation of the city}

Researchers who conducted the search on the Internet have observed that the "phrases concerning suspension of business activity and redundancies of employees have reached their highest values since the search data are collected by Google Trends (since 2004). In some cases, the scale of the growth of phrase searches is unprecedented, reaching $400 \%$ more than ever before" (Wolniak, 2020, p. 13). This proves the great importance of introducing various forms of aid for entrepreneurs. Due to the difficult situation of many entrepreneurs and residents caused by the coronavirus epidemic, the local government systematically took such actions. Since 1 April 2020, the so-called 'Anti-Crisis Shield' (a set of laws adopted by the Parliament and signed by the President to counteract the economic effects of the pandemic) has come into effect, enabling, among others, municipalities to introduce changes in the area of fees for perpetual usufruct and local taxes. Therefore, the next day, a series of draft resolutions was prepared in Zabrze containing comprehensive support and reliefs in the following cases: exemption from real estate tax, preferential rates and extension of payment of this tax, as well as waiver of the perpetual usufruct fee. The text of the ordinance on waiving fees for advertising on municipal land and along the roadway was also prepared. The City Hall was proposed to introduce the maximum level of tax reliefs and exemptions permissible by law. The aid package was finally adopted at the City Hall session on 23 April. As part of this package, entrepreneurs could postpone the date of tax payment, even apply for tax remission or for suspension of tax collection for several months. Entrepreneurs who had their premises in the city's resources or municipal companies could also apply for exemption from paying rent. The Zabrze Centre for Supporting Entrepreneurship (an entity within the structure of the Municipal Office) provided assistance to stakeholders in filling in applications for obtaining support under the prepared support measures in the city, the Social Insurance Institution or the Tax Office.

Moreover, in random incidents, at the request of people carrying out repairs of government housing facilities, the local government agreed to extend the deadline for their completion. Therefore, future tenants were not obliged to pay rent for the period when renovation works were still in progress.

Since 26 March, the collection of parking fees for a vehicle in the Unguarded Paid Parking Zone has been suspended. The proposals of discounts or deferred payment dates have also been prepared by the municipal companies, such as, e.g. Zabrze Water Supply and Sewerage Company, which guaranteed that "there will be water in the tap, breakdowns will be removed and potential delays in paying bills, caused by loss of sources of income, will not result in immediate disconnection of supplies" (introduction to the description of the support package on the company's website at wodociagi.zabrze.pl/komunikat). 
Not only economic operators were gradually restored to function. The response to social expectations, accompanied by the introduction by the government of successive stages of lifting epidemic restrictions, was the revival of sports, cultural and recreation centres. However, it did not go without creating special safety procedures.

With reference to the guidelines of the Council of Ministers concerning the defrosting of the economy and sport, as early as on 4 May, the Municipal Centre for Sport and Recreation opened five sports facilities. They were made available on special rules stipulating, among others: maximum number of six people using a given pitch (additionally a coach), and furthermore, the pitch may be used only after supervision by the facility administrator's employees, a coach or an adult person, maintaining a minimum distance of two metres and complying with the obligation to cover face. It was also required to report to the facility manager the groups interested in using the pitch in order to establish a schedule. There was no possibility to use the cloakroom and sanitary facility (except for the toilet). After each use and each consecutive group, the equipment was disinfected. Hand disinfection was mandatory for those entering and leaving the pitch and the building, and parents of children were forbidden to stay around the pitch and move around the building.

Since 6 May, the Municipal Public Library commenced making the collections available. Again, restrictions were introduced on the number of people staying on the premises at the same time. Readers were obliged to observe the general safety rules in force during the epidemic, in particular to keep a safe distance of approximately two metres, cover their nose and mouth. Additionally, it was recommended to use disinfectants available in the library. During the pandemic, free access to books on the shelves was suspended. Selected titles were given only by the librarian. All library materials (e.g. books, games, audiobooks) returning from readers were quarantined for three days. Only after that time they were made available for lending again. Some additional services provided by the library were also suspended, including the use of electronic devices and the Internet, the possibility of having a computer printout or photocopying services. The procedures given for the use of facilities show that despite the reopening of individual institutions, a strict sanitary regime was maintained, which was also reflected in the limitation of their social range.

\section{Conclusions}

The local government has employed practically all its resources to protect local communities. To ensure the functioning of the administration, the rules of teleworking were introduced, officers were equipped with appropriate equipment and the necessary procedures were created. The results of research conducted in Poland during a pandemic showed, in fact, that "remote work is possible $-33.9 \%$ of respondents had never worked remotely before the 
pandemic, during the pandemic as many as $85.6 \%$ of respondents worked five days a week" (Dolot, 2020, p. 11), which most probably will have consequences for the future principles of work organisation not only for companies, but also for public administration.

The task force established in the Zabrze City Hall together with the Department of Crisis Management and Civil Protection co-ordinated the securing of infrastructure for isolating the infected people, disinfection measures, protection and prevention. Together with social assistance, care for the people in need was organised. Schools that introduced distance learning were supported. Aid packages were developed and implemented for residents and entrepreneurs conducting business activity in Zabrze, including exemptions, tax reliefs and preferential tax rates. There were efforts to activate and integrate residents. All these efforts were properly communicated in order to provide access to reliable, up-to-date and relevant information distributed via easy-to-access media. "It is a fact that the coronavirus may affect anyone. No matter what their wealth, education or eventually their place of residence is. That is why, in every country where a case of coronavirus has been diagnosed, panic and anxiety associated with it begins to grow. As a result, there is a lot of fake news about the coronavirus everywhere" (Nowak, 2020, p. 106). The role of the local government communication services was to counteract rumours and provide accurate and objective information.

Certainly, the activities of state services were much more spectacular and comprehensive. A good example is "Shin Bet, the Israeli equivalent of the Internal Security Agency [ABW] which has been using tracking software - so far used for anti-terrorist purposes - to spy on coronavirus since the middle of March. The solution is to use geolocation in smart phones and analyse the use of credit cards to reconstruct the history and contacts of a COVID-19 patient before this person is diagnosed" (Nyzio, 2020, p. 6). The purpose was to establish with whom the infected person kept in contact in order to put them in quarantine. Nevertheless, at the level of local government entities, consistent measures were taken to provide support for the government's anti-crisis services and to ensure safety for the local community in epidemic conditions. On the scale of cities with poviat rights, the statement that "a good image may support the process of providing security" was also confirmed (Klein, 2020, p. 152). Local government, as the administrative structure closest to the community, could respond rapidly to the needs and expectations of the community. 


\section{References}

1. Długosz, P. (2020). Krakowscy studenci w sytuacji zagrożenia pandemia koronawirusa, Raport z badań: Instytut Filozofii i Socjologii Uniwersytetu Pedagogicznego im. Komisji Edukacji Narodowej w Krakowie.

2. Dolot, A. (2020). Wpływ pandemii COVID-19 na pracę zdalną - perspektywa pracownika. E-mentor, $n r 1$.

3. Edwards, L. (2018). Understanding Public Relations. Theory, Culture and Society. London: SAGE.

4. Kaczmarek-Śliwińska, M. (2020). Hejt jako źródło sytuacji kryzysowych podmiotów w przestrzeni społecznej. Zarzadzanie Mediami, $n r 2$.

5. Enli, G. (2015). Mediated Authenticity: How the Media Constructs Reality. New York: Peter Lang.

6. Klein, G. (2020). Kształtowanie wizerunku wybranych grup dyspozycyjnych. Forum Socjologiczne. Społeczne konteksty bezpieczeństwa, $t$. 10.

7. Gołuchowski, J., Paliszkiewicz, J. (2020). Zarządzanie komunikacja cyfrowa organizacji. Prace Naukowe Uniwersytetu Ekonomiczny w Katowicach. Cyfrowa komunikacja organizacji.

8. Nowak, W. (2020). Fake news w czasach zarazy. Dyskurs \& Dialog, $n r 1$.

9. Nyzio, A. (2020). Pandemia koronawirusa a polskie służby specjalne. Komentarz Katedry Bezpieczeństwa Narodowego Uniwersytetu Jagielońskiego, $n r 9$.

10. Nyzio, A. (2020). Straże gminne - problemy, wyzwania i propozycje reform. Środkowoeuropejskie Studia Polityczne, $n r 1$.

11. Sęczkowska, K. (2019). Konsekwencje psychospołeczne pracy zdalnej. Problemy Nauk Humanistycznych i Spotecznych. Teoria i Praktyka, nr 2.

12. Szpunar, M. (2020). Hiperlękowa rzeczywistość i edukacja do słabości. Forum Akademickie, $n r 3$.

13. Wolniak, R. (2020). Wyszukiwanie informacji o zwieszeniu działalności gospodarczej i zwolnieniach pracowników w internecie w wyniku pandemii koronawirusa w Polsce. Management and Quality - Zarzadzanie i Jakość, nr 2. 